УДК 553.3/9(477.82)

РЕЛЬЕФ I КЛІМАТ ЯК ПРИРОДНІ РЕСУРСИ ВОЛИНСЬКОЇ ОБЛ.

\author{
Ф. Зузук, І. Нетробчук
}

Східноєвропейський національний університет імені Лесі Украӥнки, просп. Волі 13, 43021, м. Луиььк, Украӥна

Природні ресурси, а серед них рельєф і клімат, мають надзвичайне значення не тільки для ведення господарства, а й для оздоровлення й відпочинку населення. Рельєф області рівнинний, сформований у процесі четвертинного зледеніння. Він, як ресурс, сприяє активному розвитку всіх галузей сільського господарства, будівництва шляхів сполучень і населених пунктів сільського і міського типів. "Естетичність" рельєфу є основною складовою рекреаційного ресурсу області, що визначають за 5-бальною системою. Клімат області як ресурс, а це радіаційний баланс, вітровий і тепловий режим, вологість, опади, сніговий покрив, особливості пір року, забезпечує неризиковане землеробство області, зокрема, всі галузі рослинництва, а відповідно, і тваринництва, птахівництво, рибництво, бджільництво. Завдяки кліматичному ресурсу в області добре розвинуте лісове господарство. Кліматичний ресурс у сукупності із густою річковою мережею та наявністю великої кількості озер має надзвичайно важливе значення для рекреації. Найсприятливішими для відпочинку є червень, липень і серпень.

Ключові слова: ресурс, рельєф, клімат, сільське господарство, лісове господарство, рекреація.

Проблема природних ресурсів та їхнього раціонального використання з року в рік стає щораз актуальнішою. Рельєф і клімат Волинської обл. як ресурс використовують не тільки для сільськогосподарського виробництва, а й для відпочинку та оздоровлення місцевого населення і приїжджих громадян із суміжних областей України, а також сусідніх Білорусі та Польщі. Важливе значення рельєф і клімат мають для забудови населених пунктів, особливо міст, а також їхнього комунального господарства, зокрема опалення. У разі вирішення згаданих вище проблем обов'язково враховують особливості рельєфу та клімату.

Роль рельєфу i клімату в системі природних ресурсів розглянуто в працях О. Маринича і П. Шищенка [3, 16], Ю. Зінька, І. Ковальчука [6], І. Залеського [8, 9]. Науково обгрунтовану інформацію про рельєф Волинської обл. знаходимо в працях П. Тутковського [23], О. Маринича [16], К. Геренчука [3]. Взаємозв'язок неотектоніки й рельєфу розглядає В. Палієнко [19]. Льодовикові форми рельєфу з позиції сучасного розвитку науки досліджували Л. Дорофеєв [7], А. Богуцький [2], І. Залеський [9] та ін. Карстові форми рельєфу найдетальніше вивчав М. Федонюк [24].

Перший крок у вивченні клімату зробив С. Бржозовський [4], який у Волинській губернії організував дощомірну мережу. На 1914 р. вона налічувала 22 станції, 141 дощомірних і 19 снігомірних постів. 31925 р., за іншою інформацією - з 1929 р., почалися метеоспостереження в аеропорту м. Луцьк. У 1940 р. метеослужба УРСР сформувала метеостанцію другого розряду. 31941 до 1944 р. спостереження не проводили. У 1944 р. метеостанція відновила роботу. У 1955 р. організовано Волинське гідрометбюpo, a 1957 р. видано перший “Агрокліматичний довідник по Волинській області” [1] (виходив до 1961 року). У січні 1985 р. гідрометбюро реорганізовано в гідрометобсер-

(C) Зузук Ф., Нетробчук I., 2014 
ваторію [4]. Останнім часом результати спостережень передають у Центральну геофізичну обсерваторію (м. Київ). Безпосередньо клімату області присвячені праці $[5,13,14,17,20,21]$.

Наша мета - вивчення рельєфу і клімату Волинської області як складових природних ресурсів. Під час виконання досліджень використовували матеріали Волинського центру гідрометеорології, а також опублікованих наукових праць. У ході вивчення й оцінки рельєфу і клімату як природних ресурсів інформацію опрацьовували порівняльним і статистичним методами досліджень.

Рельєф - це одна з важливих складових природного комплексу, що суттєво впливає на його господарські та рекреаційні можливості. Він чинить як позитивну, так і негативну дію на господарську і рекреаційну діяльність. Як найважливіший компонент і основа ландшафту, рельєф визначає фізіономічні риси природного комплексу.

Волинська обл. розташована в межах полігенної рівнини України, де виділяють Поліську низовину та Волино-Подільську височину. У межах Поліської низовини є сім геоморфологічних районів. Тут поширені рівнинні флювіогляціальні, гляціальні, алювіальні поверхні перших і других терас, а також голоценові утворення заплав і боліт. Ці рівнинні поверхні ускладнені утвореннями кінцевих морен та дюнами еолового походження.

Волинська височина належить до Волинського лесового височинного геоморфологічного району. Вона вирізняється еолово-делювіальними поверхнями зі значною розчленованістю рельєфу, що спричинено базисом ерозії та високою здатністю до ерозії лесових порід, що залягають на крейдовій основі. Загалом рельєф Поліської низовини і Волинської височини, незважаючи на їхню певну відмінність, як природний ресурс сприяє розвитку сільськогосподарського виробництва, будівництва населених пунктів і доріг та має значні рекреаційні можливості.

Найбільше значення в сільськогосподарському виробництві має Волинський лесовий височинний геоморфологічний район, а в рекреаційному - Шацький вододільний горбисто-западинний карстово-озерний геоморфологічний район. В обох випадках враховують морфометричні показники рельєфу: абсолютні висоти, відносні перевищення, ступінь вертикального і горизонтального розчленування, крутість та експозиція схилів. У випадку рекреації важливе значення має прохідність (доступність) території, оглядовість, різноманітність, привабливість, наявність пам'яток природи.

Зазначимо, що питання естетики рельєфу, тобто однієї із важливих складових рекреаційної "вартості” території, сьогодні значно зацікавили науковців та практиків. Зокрема, сьогодні відомі різні оцінки рельєфу для потреб рекреаційного освоєння території чи планування різних видів відпочинкової діяльності. Наприклад, Ю. Симонов, В. Кружалін [22] запропонували функціонально-технологічний (нормативний) підхід для оцінки рельєфу 3 метою його рекреаційного використання. Екологоприродоохоронний підхід для геоморфологічного оцінювання ландшафтів запропонували в $[6,15]$.

Рельєф є ресурсозабезпечувальним чинником, що визначає рекреаційні властивості території, вид іiі діяльності та будівництво відповідної інфраструктури [12]. Н. Карпенко запропонувала п’ятибальну шкалу з метою рекреаційної оцінки рельєфу. Бальна оцінка грунтується на морфометричних показниках. Чим більша сума морфометричних балів, тим вища рекреаційна оцінка. Загалом для Поліської низовини і Волинської височини з метою функціональної рекреаційної оцінки рельєфу вибрано три головні функції: спортивно-туристську, прогулянкову і відпочинкову. 
Рельєф як природний ресурс розглянемо на прикладі Шацького вододільного горбисто-западинного карстово-озерного геоморфологічного району Поліської низовини та геоморфологічного району Волинська лесова височина для Волинської височини.

Шаиький вододільний горбисто-западинний карстово-озерний геоморфологічний район добре вивчений [11]. Абсолютні висоти в межах району коливаються від 154,9 до 189,4 м. Найнижчі позначки є на заплавах річок Прип’ять - 165-170 м, Західний Буг - 155-160 м, Копаївки - 158-161 м. Максимальні абсолютні позначки - моренного (175-185 м) та еолового (170-175 м) походження. Вертикальне розчленування рельєфу становить пересічно 3-5 м/км². Найменші відносні перевищення $(0,3-0,6$ м) наявні на озерно-алювіальній та зандровій рівнинах. Відносні перевищення моренного рельєфу сягають 5-15 м. Горизонтальне його розчленування становить $0,1-0,4$ км/км², лише подекуди воно збільшується до 1,1 км/км². Територія поозер'я має незначний похил на північ і північній захід. Алювіальний рельєф території плоский за кутів нахилу $0^{\circ} 30^{\prime}-$ $3^{\circ}$, для водно-льодовикового він становить $1-5^{\circ}$, а для моренного $-3-7^{\circ}$. Для еолових форм кут нахилу поверхні зростає до $10^{\circ}$ і більше [11]. На Шацькому поозер’ї поєднані реліктові льодовикові й водно-льодовикові типи рельєфу з карстовими, еоловими, ерозійними та антропогенними. Окремо виділяється озерний тип рельєфу, утворений карстово-льодовиково-акумулятивними типами озерних улоговин.

Загалом рельєф Шацького вододільного горбисто-западинного карстово-озерного геоморфологічного району - ресурс, сприятливий для розвитку лісового господарства, рибництва, бджільництва. Сільськогосподарське виробництво в районі має місцеве значення, що зумовлено поширенням малопродуктивних дернових грунтів та заболоченістю території. Незначний похил рельєфу в межах меліорованих заболочених земель Копаївської системи сприяє їхньому активному вторинному заболоченню, що спричинено насамперед неврахуванням особливостей рельєфу під час ії будівництва. Рельєф цього геоморфологічного району має найвищий бал для рекреаційної діяльності: курортно-лікувальної, спортивно-оздоровчої й пізнавальної (Світязька озерна низовина), спортивно-оздоровчої й пізнавальної (Ростанське кінцево-моренне пасмо, Прибузька алювіальна рівнина, Копаївська алювіально-зандрова низовина, Прип’ ятська алювіальна низовина).

Волинський лесовий височинний геоморфологічний район розміщений на півдні області. Еолово-делювіальна поверхня верхньочетвертинного віку суміщена із заплавою Західного Бугу, Стиру та їхніх приток, надзаплавною терасою Стиру та Західного Бугу, а також двома значними зонами флювіогляціальної полого-хвилястої поверхні дніпровського зледеніння [10].

У центральній частині височини рельєф слабко розчленований і сформований вирівняними, злегка хвилястими, поверхнями. Середні висоти становлять 230-240 м за максимуму 279 м, а перевищення сягає 30-40 м, інколи до 70 м. Горизонтальне розчленування рельєфу зазвичай становить $1,0-1,5$ км/км² за максимального 1,7 км/км² ${ }^{2}$ Вертикальне розчленування може сягати $10 \mathrm{M} / \mathrm{\kappa m}^{2}$ за пересічного 5-7 м/км². Пересічні кути похилу рельєфу становлять $1-2^{\circ}$, максимум - майже $4^{\circ}$. Тераси річок Західний Буг i Луга майже не розчленовані. Там, де проходить Головний Європейський вододіл, вертикальне розчленування становить $8-12$ м/км², а горизонтальне $-1,2-1,7$ км/км² за кутів похилу 2,5-4,0 . Далі на схід до р. Стир і на її терасах територія знову стає рівнинно-хвилястою, слабко розчленованою [18].

На півночі й півдні височини висоти пересічно становлять 240-250 м за максимуму 288 (с. Садів) та 292 м (с. Брани). Перевищення пересічно сягає 50-80 м, максимум - 
90-100 м. Вертикальне розчленування рельєфу для північної і південної частини становлять 5-7 м/км² за максимуму, відповідно, 12 та 14 м/км². Пересічні значення горизонтального розчленування рельєфу $-1,6-1,7$ км/км ${ }^{2}$. У південній частині показники горизонтального розчленування не перевищують $1,6-1,7$ км/км² за максимуму 2,0 км/км². Кути похилу рельєфу Волинського лесового височинного геоморфологічного району сягають $1-2^{\circ}$ зі зростанням на південний схід до $3-4^{\circ}$.

Наведені вище результати морфометричного аналізу засвідчують, що рельєф цього геоморфологічного району як природний ресурс за наявності чорноземів, сприятливий для інтенсивного сільськогосподарського виробництва, зокрема таких галузей, як вирощування зернових, цукрових буряків, городництва, садівництва, тваринництва, птахівництва. Бальна рекреаційна оцінка рельєфу засвідчує, що його можна використовувати для відпочинкової і прогулянкової функції, можлива також спортивно-туристська діяльність.

Кліматичні ресурси визначають не тільки можливість вирощування на території тих чи інших сільськогосподарських культур, а й ії комфортність для відпочинку й оздоровлення людей. Клімат як ресурс характеризують низкою показників: радіаційним і світловим режимом, атмосферною циркуляцією, термічним і зволожувальним режимами, хмарністю, порами року тощо.

Радіаційний і світловий режим $є$ астрономічним чинником і прямо залежить від положення сонця на небосхилі в різний час року і доби та часом, коли сходить і заходить сонце. На широті області довжина дня впродовж року значно змінюється. Зокрема, найкоротший день - 8,6 год - i, відповідно, найменша висота сонця в полудень $16,0^{\circ}$ простежується в грудні, а найдовший - 16,3 год - у червні за висоти сонця опівдні $62,6^{\circ}$. Тривалість сонячного сяйва залежить від довжини дня, хмарності та закритості горизонту. Найменша тривалість місячної суми сонячного сяйва зафіксована в грудні 37 год, тобто $15 \%$ від можливого, оскільки день найкоротший і висока ймовірність хмарності. У червні тривалість місячної суми сонячного сяйва - 268 год, або $54 \%$ від можливого. Найстабільніша тривалість сонячного сяйва простежується з травня до вересня включно. Найбільші коливання фіксують узимку, що спричинено хмарністю. Загалом радіаційний баланс на півдні області становить 1718 мДж/ ${ }^{2}$, а на півночі $1400 \mathrm{мДж/ \textrm {m } ^ { 2 }}$ [14] .

Зазначимо, що радіаційний баланс області сприятливий для вегетації і розвитку рослинного світу, а також вирощування сільськогосподарських культур. У рекреаційній діяльності ультрафіолетова радіація має бактерицидну і вітаміноутворювальну дію. Наприклад, 1/4 лікувальної біодози ультрафіолетової радіації в липні опівдні за ясного неба можна отримати за 18 хв. Загалом режим сонячного сяйва в області сприяє довготривалим прогулянкам і походам [25].

Атмосферна циркуляція має чітко виражені сезонні властивості. Волинь перебуває під впливом Атлантичного океану - а це м'яка з частими відлигами зима і порівняно прохолодне літо з достатнім зволоженням. Західне перенесення повітряних мас із Атлантики супроводжується циклональною і антициклональною діяльністю. Циклони й улоговини становлять 43 \% від усіх баричних утворень. Західні циклони приходять із Центральної Європи, північно-західні - з Балтійського моря та Скандинавії, а північні з Баранцевого моря. У тилу циклонів відбуваються вторгнення антициклонів, зазвичай це ядра Азорських утворень. Узимку наявні гребені високого тиску, пов'язані з Сибірським антициклоном, а також антициклони із півночі і північного сходу, що приносять холодне арктичне повітря. 
Bimep. Упродовж року переважають вітри західного і північно-західного напряму. Улітку швидкість вітру становить 2,7-3,8 м/с, а взимку - 4,1-4,5 м/с. За добу максимальну швидкість вітру фіксують у післяобідній час, а мінімум - у другу половину ночі, зокрема, перед ранком. Шквальні вітри швидкості 15 м/с і більше бувають дуже зрідка.

Згадані вище швидкості вітру, на жаль, не дають змоги використовувати його як джерело енергії. 3 іншого боку, майже відсутність шквальних вітрів улітку не призводить до вилягання зернових культур, а це - збереження урожаю, взимку не "заметені" дороги, що важливо для транспортних перевезень. Улітку в спекотні дні в зонах рекреації, тобто на пляжах річок і озер, легкий вітерець сприяє комфортності відпочинку.

Термічний режим $є$ головним метеорологічним показником. Він визначений кількістю радіації та особливостями підстильної поверхні.

Середньомісячна температура повітря у січні становить $-5,1^{\circ} \mathrm{C}$, у лютому $--4{ }^{\circ} \mathrm{C}$. Від лютого до травня вона підвищується на $4-6{ }^{\circ} \mathrm{C}$, від травня до липня - поступово на $1,5-3,0^{\circ} \mathrm{C}$. У квітні пересічна температура сягає $7,0-7,3{ }^{\circ} \mathrm{C}$, у травні $-13,7-13,9{ }^{\circ} \mathrm{C}$, червні, липні, серпні - $16,8-18,8^{\circ} \mathrm{C}$. Найтеплішим є липень $-18,4-18,8^{\circ} \mathrm{C}$. У вересні пересічні значення температури близькі до травневих $-13,0-13,7^{\circ} \mathrm{C}$. У період від вересня до грудня температура знижується на $4,5-5,5^{\circ} \mathrm{C}$. У грудні вона становить пересічно 2,5 ${ }^{\circ} \mathrm{C}$. Зазначимо, що з березня до листопада включно температура додатна, із травня до вересня - вище $10^{\circ} \mathrm{C}$, а в червні-серпні вище $15^{\circ} \mathrm{C}$. Річна амплітуда температури становить $24^{\circ} \mathrm{C}$.

Середньодобова температура повітря найнижча пересічно з 5 січня до 11 лютого, а вже 312 лютого вона починає підвищуватися і 21 березня стає додатною. Середньодобову температуру повітря вище $15^{\circ} \mathrm{C}$ фіксують 327 травня до 9 вересня. Найвища добова температура $\left(19^{\circ} \mathrm{C}\right)$ простежується пересічно з 12 липня до 10 серпня. Після цього відбувається поступове зниження температури одночасно зі зменшенням тривалості дня. Із 6 грудня середня добова температура повітря стає від'ємною. Коливання середньодобової температури найбільші навесні $\left(20,6{ }^{\circ} \mathrm{C}\right)$ і восени $\left(15^{\circ} \mathrm{C}\right)$. Узимку значне коливання добової температури, зазвичай, типове для січня. У літні й зимові місяці різниця між найтеплішими і найхолоднішими добами пересічно не перевищує $4{ }^{\circ} \mathrm{C}$. Середньодобова температура повітря суміжних діб змінюється дуже мало - не більше, ніж на $1{ }^{\circ} \mathrm{C}$. Найбільша мінливість пересічної добової температури фіксована взимку $7,6^{\circ} \mathrm{C}$, менша навесні $-4^{\circ} \mathrm{C}$, а восени знову зростає і становить $4,9^{\circ} \mathrm{C}$ [13-14].

Відомо, що майже 80-85 \% річного тепла припадає на весну і літо, тобто на період активної вегетації рослин, зокрема сільськогосподарських культур. Тривалість безморозного періоду пересічно триває від 154 (с. Любешів) до 165 (с. Світязь) днів на півночі області, а на півдні (Луцьк) становить 164 дні [13-14]. Більшість сільськогосподарських культур вегетує після переходу середньодобової температури навесні через $+5{ }^{\circ} \mathrm{C}$. Сума температур вище $+5{ }^{\circ} \mathrm{C}$ становить $2840-2930{ }^{\circ}$. Теплолюбні культури вегетують за температур повітря $+10^{\circ} \mathrm{C}$ і вище, у сумі $2495-2580^{\circ}$.

Тепловий режим області узгоджується із безморозним періодом. Він безпосередньо впливає на вегетацію рослинного світу лісів (мішаних і широколистяних), лук і боліт, а також сільськогосподарських культур. Власне температурний режим як ресурс сприяє інтенсивному розвитку багатогалузевого сільського господарства Волині. Він відіграє позитивну роль для комфортного проживання населення області, а також для його відпочинку й оздоровлення.

Заморозки весняні на Волині припиняються пересічно наприкінці квітня. Залежно від особливостей весни вони можуть припинитися на місяць і більше раніше або пізні- 
ше. Осінні заморозки зазвичай фіксують наприкінці першої декади жовтня або в середині вересня чи на початку листопада.

Температура трунту взимку становить від $-2,5$ до $-5,8^{\circ} \mathrm{C}$, найбільша вона в січні. Навесні різко підвищується: в березні сягає $1,2^{\circ} \mathrm{C}$, у квітні $-9,2^{\circ} \mathrm{C}$, травні $-17^{\circ} \mathrm{C}$. Найвища температура грунту влітку, коли вона на $3-4{ }^{\circ} \mathrm{C}$ вища від температури повітря. Осіння температура грунту від місяця до місяця зменшується на $6-7^{\circ} \mathrm{C}$. У листопаді вона додатна $-2,3^{\circ} \mathrm{C}$. Річна амплітуда температури грунту пересічно становить $27,6^{\circ} \mathrm{C}$.

Заморозки грунту навесні фіксують у половині першої декади травня, а восени - у середині першої декади жовтня. Безморозний період на грунті становить 157 днів, тобто він коротший, ніж для повітря. Промерзання грунту $\left(0{ }^{\circ} \mathrm{C}\right)$ в січні сягає 24 см, лютому -33 см, а під озимою пшеницею в грудні - 22 см, у лютому - 38 см [14].

Температура грунту як ресурс має особливе значення для зимівлі лісових, болотних і лучних фітоценозів, а також багатьох тварин. В області, як бачимо з наведеного вище опису, він $є$ сприятливим не тільки для зимівлі природних фітоценозів, а й сільськогосподарських культур, зокрема, озимих злакових та ріпаку.

Режим зволоження. Найбільша відносна вологість повітря - взимку, у грудні становить $87 \%$. Вона також висока у січні, лютому і листопаді, а від березня до квітня знижується на $7 \%$. У березні відносна вологість становить $80 \%$, травні - $70 \%$; у літні місяці знижується до 70-75\%, хоча о 13 год. становить 40-60\%. Максимальна вологість повітря - перед сходом сонця. Вологих днів найменше влітку. Упродовж року фіксують 112 вологих днів, серед них на холодну пору року припадає 93 [13-14].

За рік атмосферних опадів випадає 591 мм. Зокрема, їх може бути більше або менше норми на 40-50\%. Волинь вирізняється континентальним типом річного ходу опадів 3 максимумом 70-80 мм улітку. Найменше опадів випадає взимку і в березні, тобто на початку весни, хоча $є$ роки, коли хід опадів зміщується. Найбільші коливання місячної кількості опадів характерні для літа, найменші коливання з року в рік простежуються у березні та грудні. Узимку майже половина опадів випадає у вигляді снігу. Найбільша кількість днів, коли випадає сніг, $є$ в січні, дощ - у грудні, сніг та дощ - у лютому. Загальна кількість опадів, що випадають на Волині за рік, зростає 3 північного заходу на схід-південний схід. На Шацькому поозер'ї їхня кількість становить 550 мм, у Ковелі - 550-600 мм, а смт Маневичі - 650 мм. У холодний період - листопадберезень - випадає пересічно 169 мм за максимуму 350 мм і мінімуму - 90 мм. Для теплого періоду, тобто квітня-жовтня характерна більша кількість опадів - пересічно 431 мм за максимуму 620 мм і мінімуму 178 мм [13, 14, 17].

Атмосферні опади є особливим кліматичним ресурсом, оскільки вони забезпечують життєдіяльність усього рослинного, а також тваринного світу області i, зокрема, сільськогосподарських культур. Область розміщена в зоні неризикованого землеробства. Хоча в окремі роки надлишок опадів може завдавати шкоди сільськогосподарському виробництву. Кількість опадів у літні місяці, зазвичай створює комфортні умови відпочинку для жителів різного віку.

Стійкий сніговий покрив формується наприкінці грудня, тобто за два тижні до того, як середня добова температура повітря стає нижче $-5^{\circ} \mathrm{C}$. Він на південному заході області до межі Любомль - Турійськ зберігається до 70 днів, а північніше межі впадіння Турії в Прип'ять - смт Маневичі - може існувати від 70 до 80 днів, а далі на схід від згаданої межі зберігається понад 80 днів. Бувають роки, коли сніговий покрив існує до 31 дня, а інколи з 8 грудня до 30 березня (1963-1964, 2012-2013), тобто 112 днів. Спостереження засвідчують, що у $20 \%$ зим сніговий покрив може не формуватися. Висота 
снігового покриву мінлива. Наприклад, у грудні вона становить 5-10 см, у січні - 1015, лютому - 15-20 см. В окремі роки у березні товща снігу може сягати 35 см (2013). Після добової температури $0^{\circ} \mathrm{C}$ він повністю тане.

Сніговий покрив $є$ важливим ресурсом у господарстві, оскільки відіграє значну роль для успішної зимівлі озимих культур. Крім того, в окремі роки його можна успішно використати для зимових видів спорту і відповідного відпочинку.

Пори року. Зима. 3 переходом температури через $0{ }^{\circ} \mathrm{C}$ настає зима. Зазвичай, це відбувається на початку грудня. Один раз у 20 років зима може починатися в першій половині листопада або наприкінці грудня. Найхолодніший період узимку, коли добова температура становить $-5^{\circ} \mathrm{C}$, настає на початку січня, і триває до початку лютого і становить 27 днів та більше. Переважно зима продовжується 100 днів і більше. Узимку різке похолодання пов'язане 3 поширенням відрогів сибірського антициклону, а також iз антициклонами зі Скандинавії. Температуру повітря $10{ }^{\circ} \mathrm{C}$ і нижче фіксують 3 листопада до березня. Найбільше холодних днів припадає на січень і лютий. Пересічно низька температура може бути до 27 днів, а інколи до 60 і більше. Найчастіше такі дні бувають у лютому. В аномально холодні зими температура може знижуватись до $-30{ }^{\circ} \mathrm{C}$ i стояти декілька днів. Таке може повторюватися три роки на десять років [13-14].

Відлиги настають, коли температура повітря підвищується до $0{ }^{\circ} \mathrm{C}$ і більше. Це буває, коли маємо надходження теплих повітряних мас із Середземного і Чорного морів та Атлантики. За зиму фіксують 46 днів із відлигою. Найбільше їх у грудні (19), а менше у січні та лютому - 13-14. Зазвичай, відлига триває шість днів. Температура повітря під час відлиг може сягати $12-15^{\circ} \mathrm{C}$. У цьому разі можливі навіть тумани [14].

Весни бувають ранні й пізні, а за температурним режимом - теплі й холодні. Ранні весни, зазвичай, теплі, середньомісячна температура вище норми, опадів випадає мало, а пізні весни - холодні й затяжні, погода похмура, з частими дощами, температура повітря нижче норми. Перша половина весни зберігає ознаки зими, друга супроводжується переходом до добової температури вище $5^{\circ} \mathrm{C}$, а пізніше - до $10^{\circ} \mathrm{C}$, зазвичай у третій декаді квітня. Весна - найкоротша пора року - 70 днів.

Літо. У цю пору року добова температура переходить через $15^{\circ} \mathrm{C}$. Літо починається, зазвичай, у третій декаді травня, а раз у 20 років - у другій декаді травня або в середині червня. Погода влітку нестійка, з його початком настають грози. Воно може бути сухе й вологе, гаряче і холодне. Літо триває 90-100 днів. Для довгого літа характерна висока середня добова температура повітря, незначна кількість опадів і велика кількість сонячних днів, а для холодного - порівняно нижча добова температура, більша кількість опадів і значна кількість похмурих днів. Висока середньодобова температура понад $25^{\circ} \mathrm{C}$ може бути з травня до вересня, зазвичай, 10-12 днів. Вона $є$ некомфортною для Волині.

Осінь настає, коли середня добова температура повітря нижче $15{ }^{\circ} \mathrm{C}$. Зниження зумовлене заходженням арктичного холодного повітря. У такому випадку зростає кількість днів із туманами. На початку вересня-жовтня наступає тепла, суха, тиха погода, тобто період “золотої осені”. 3 переходом температури через $10{ }^{\circ} \mathrm{C}$ в бік зниження закінчується вегетація теплолюбних культур. Зазвичай, наприкінці жовтня температура переходить через $5{ }^{\circ} \mathrm{C}$, вегетація припиняється. Період 3 температурою повітря $5{ }^{\circ} \mathrm{C}$ i вище становить дещо більше 200 днів. Осінь триаває дещо більше трьох місяців.

Пори року $є$ важливим природним ресурсом. Завдяки їхньому температурному i вітровому режиму, вологості повітря й кількості опадів нормально розвивається і функціонує лісова, лучна і болотна рослинність та дикий тваринний світ області. Природ- 
ний ресурс пір року дає змогу вирощувати в області зернові, льон, буряки, овочі, плодово-ягідні культури, розвивати тваринництво, птахівництво, рибництво, бджолярство, мисливство.

Пори року як рекреаційний ресурс відіграють особливу роль для вирішення проблем сучасної рекреації, найсприятливішим для цього є літо, дещо менші можливості зими. Весна і осінь несприятливі для відпочинку.

Отже, рельєф як природний ресурс відіграє важливу роль у всебічному господарському розвитку області, оскільки він рівнинний і це дає змогу активно розвивати сільське господарство, будівництво доріг, раціонально розміщувати населені пункти. Рівнинний рельєф за наявності відповідної річкової мережі й озер є дуже сприятливим для розвитку рекреаційної інфраструктури. У сукупності все це добре видно на прикладі Шацького вододільного горбисто-западинного карстово-озерного геоморфологічного району та району Волинської лесової височини.

Клімат є особливо важливим природним ресурсом. Завдяки клімату область перебуває в зоні неризикованого землеробства. Радіаційний баланс, вітровий і температурний режим, особливості зволоження, сніговий покрив, пори року в сукупності сприяють розвитку всіх галузей сільського і лісового господарства, рибництва і бджільництва. Кліматичний ресурс має важливе значення для інтенсивного розвитку рекреації. Найсприятливішими місяцями для рекреації є червень, липень і серпень.

Загалом рельєф і клімат як природні ресурси заслуговують на подальші дослідження, що сприятиме раціональному всебічному розвитку галузей господарства Волинської обл.

\section{СПИСОК ВИКОРИСТАНОЇ ЛІТЕРАТУРИ}

1. Агрокліматичний довідник по Волинській обл. - К. : Держсільгоспвидав, 1959. $85 \mathrm{c}$.

2. Богуиький А. Б. Плейстоценові зледеніння Волинського Полісся / А. Б. Богуцький, I. І. Залеський // Українське Полісся: вчора, сьогодні, завтра : зб. наук. праць. Луцьк : Надстир'я, 1998. - С. 100-102.

3. Геренчук К. И. Волынское Полесье / К. И. Геренчук // Физико-географическое районирование Украинской ССР / [под ред. А. М. Маринина]. - Киев : Изд-во Киев. ун-та, 1968. - С. 36-52.

4. Гидрометеорологическая служба Украины за 50 лет Совесткой власти. - Л. : Гидрометеоиздат, 1970. - $270 \mathrm{c.}$

5. Головко I. К. Клімат Полісся України / І. К. Головко // Нариси про природу і сільське господарство Українського Полісся. - К. : Вид-во КДУ, 1955. - С. 25-31.

6. Горішний П. М. Рекреаційна оцінка рельєфу пропонованого Розтоцького національного парку / П. М. Горішний, Ю. В. Зінько, М. В. Кобелька // Вісник Львів. ун-ту. Сер.: геогр. - 1994. - Вип. 19. - С. 12-18.

7. Дорофеєв Л. М. Льодовикові та водно-льодовикові відклади / Л. М. Дорофеєв // Стратиграфія УРСР. Т. ХІ : Антропоген. - К. : Наук. думка, 1969. - С. 147-170.

8. Залеский И. И. Краевые ледниковые образования северо-запада Украины в районе Любомль-Шацк / И. И. Залеский // Краевые образования материковых оледенений: материалы V Всесоюзн. совещ. - Киев : Наук. думка, 1978. - С. 89-96. 
9. Залеський I. I. Вік еолових форм у районі смт Маневичі / І. І. Залеський, П. Зелінський, С. Федорович // Природа Західного Полісся та прилеглих територій : зб. наук. пр. / відп. ред. Ф. В. Зузук. - Луцьк : РВВ “Вежа”, 2008. - № 5. - С. 8-13.

10. Зузук Ф. В. Осушені землі Волинської області : моногр. /Ф. В. Зузук, Л. К. Колошко, 3. К. Карпюк. - Луцьк : Волин. нац. ун-т ім. Лесі України, 2012. C. $18-27$.

11. Карпенко Н. I. Рекреаційні властивості рельєфу Шацьких озер / Н. І. Карпенко // Наук. вісник Волин. держ. ун-ту ім. Лесі Українки. Географічні науки, 2007. - Т. 2. Ч. 1. - С. $81-86$.

12. Карпенко Н. I. Методичні рекомендації до курсу "Рекреаційна оцінка рельєфу" / Н. І. Карпенко, П. М. Горішній, Ю. В. Зінько. - Л. : Вид. центр ЛНУ ім. І. Франка, 2005. - $46 \mathrm{c}$.

13. Клімат Шацького національного парку / Я. О. Мольчак, Б. П. Клімчук, Ф. П. Тарасюк, Н. А. Тарасюк. - Луцьк : РВВ “Вежа”, 1995. - 146 с.

14. Климат Луцка / под ред. В. Н. Бабиченко, Ф. В. Зузука. - Л. : Гидрометеоиздат, 1988. - $180 \mathrm{c}$.

15. Кравчук Я. С. Інженерно-геоморфологічне картографування / Я. С. Кравчук. Львів : Світ, 1991. - 144 с.

16. Маринич А. М. Геоморфология Южного Полесья / А. М. Маринич. - Киев : Изд-во Киев. ун-та, 1963. - 252 с.

17. Мольчак Я. А. Режим осадков в Шацком ПНП / Я. А. Мольчак, Ф. П. Тарасюк, Н. А. Тарасюк // Природопользование Волынской области. - Луцк : Волын. обл. типография, 1990. - С. 60-69.

18. Нетробчук I. М. Рекреаційна оцінка рельєфу Буго-Стирського межиріччя Волинської височини / I. М. Нетробчук // Науковий вісник Волин. нац. ун-ту ім. Лесі Українки. Геогр. науки. - 2009. - № 10. - С. 40-45.

19. Палиенко В. П. Особенности гляциорельефа краевой зоны днепровского ледника в пределах Волынского Полесья / В. П. Палиенко // Материалы по изучению четвертичного периода на территории Украины. - Киев : Наук. думка, 1982. - С. 203-211.

20. Природа Волинської області / [за ред. К. І. Геренчука]. - Львів : Вища школа, 1975. $-147 \mathrm{c}$.

21. Процьь Г. Кліматичні особливості Шацького Поозер'я / Г. Проць // Вісн. Львів. унту. Сер. геогр. - 1992. - Вип. 18. - С. 66-69.

22. Симонов Ю. Г. Инженерная геоморфология / Ю. Г. Симонов, В. И. Кружалин. М.: Изд-во Моск. ун-та, 1993. - 208 с.

23. Тутковский П. А. Ископаемые пустыни Северного полушария / П. А. Тутковский. - М., 1910. - $374 \mathrm{c}$.

24. Федонюк M. А. Обсяги карстової денудації в межах басейнів річок Волинського Полісся / М. А. Федонюк // Гідрологія, гідрохімія і гідроекологія. - 2002. - Вип. 4. - C. 256-260.

25. Фоменко Н. В. Рекреаційні ресурси та курортологія / Н. В. Фоменко. - К. : Центр навч. л-ри, 2007. -312 с. 


\title{
RELIEF AND CLIMATE AS NATURAL RESOURCES OF VOLYN REGION
}

\author{
F. Zuzuk, I. Netrobchuk
}

\author{
Eastern European National University of Lesya Ukrainka, \\ Voli Pr., 13, Lutsk, 43021, Ukraine
}

\begin{abstract}
Natural resources, among them relief and climate are extremely important not only for the economy, but also for the recreation and rest of the people. The relief of the region is flat, formed in the process of Quaternary ice period. Considered as a resource, the relief contributes to the active development of all the fields of agriculture, building of the road links and also towns and villages. The "aesthetic" character of the relief is the main component of the recreational resource of the region, the latter being estimated according to the five-grade system. Considered as a resource, the climate of the region-including its radiation balance, wind and temperature patterns, humidity, precipitation, snow cover, the peculiarities of the seasons of the year-provides non-venturesome farming of the region, in particular all branches of plant-growing and consequently poultry-farming, cattle-growing, fish-breeding and beekeeping. Thanks to its climatic resource the region enjoys a highly developed forestry. The climate resource in combination with the dense network of rivers and a great number of lakes is very important for recreation. The months most favorable for rest are June, July and August, e. i. summer.

Key words: resource, relief, climate, agriculture, forestry, recreation.
\end{abstract}

\section{РЕЛЬЕФ И КЛИМАТ КАК ПРИРОДНЫЕ РЕСУРСЫ ВОЛЫНСКОЙ ОБЛ.}

\section{Ф. Зузук, И. Нетробчук}

Восточноевропейский начиональный университет имени Леси Украинки, просп. Воли, 13, г. Луик, 43021, Украина

Природные ресурсы, в частности рельеф и климат, имеют чрезвычайное значение не только для ведения хозяйства, но и для оздоровления и отдыха населения. Рельеф области равнинный, сформированный в процессе четвертичного оледенения. Он, как ресурс, способствует активному развитию всех отраслей сельского хозяйства, строительства путей сообщений и населенных пунктов сельского и городского типов. “Эстетичность” рельефа есть главной составляющей рекреационного ресурса области, который определяется по 5 бальной системе. Климат области как ресурс, обеспечивает не рискованное земледелие области, в частности, все отрасли растениеводства, а соответственно и скотоводства, птицеводство, рыбоводство, пчеловодство. Благодаря климатическому ресурсу в области хорошо развито лесное хозяйство. Климатический ресурс вместе с густой речной сетью и наличием большого количества озер имеет чрезвычайное большое значение в рекреации. Самыми благоприятными для отдыха являются июнь, июль и август, тоесть лето.

Ключевые слова: ресурс, рельеф, климат, сельское и лесное хозяйство, рекреация. 